\title{
Job Satisfaction among Academic Cataloger Librarians
}

\author{
Joan M. Leysen and Jeanne M. K. Boydston
}

This article details the results of a May 2007 study of job satisfaction of cataloger librarians at ARL member libraries in the United States. Eightyeight percent of the cataloger librarians studied were satisfied with their current job and the majority would make the same career choice again. Job facets that cataloger librarians found most important were the benefits package, relationships with coworkers, and opportunities to learn new skills. Catalogers wanted to be treated fairly, be consulted about issues directly related to their work, be informed about current activities in their department, have their opinions respected and considered, and have an administration that supports catalogers. Topics for future research are suggested.

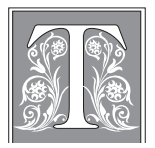

he library profession is currently undergoing a period of unprecedented change. While this change affects the library as a whole, it is especially being felt in cataloging departments. The catalog, once the primary means of accessing collections, now coexists on a library's Web page with an array of search tools and competes with popular search engines like Google and Amazon.com. Thus, libraries are directing increased attention to repositioning the catalog, enhancing its features, and evaluating its functionality. Enhancements to searchand-display functions (relevance ranking, faceted browsing, and hot links to full text), the addition of "enriched content" (book covers, tables of contents, and editorial reviews), and the provision of personalization options are some of the recent attempts by librarians to satisfy the growing expectations and preferences of library users. The electronic environment, with its emerging formats and various avenues of distribution, continues to present challenges. In addition, the number of cataloger librarians is diminishing due to retirements and the availability of fewer new graduates to replace them. ${ }^{1}$

In the midst of all this change, cataloger librarians are taking on additional roles and responsibilities while still performing the traditional cataloging functions. Discussions are taking place within academic libraries, and some of the outcomes of these conversations have been shared with the library community. ${ }^{2}$ Thoughtprovoking papers by leaders in the cataloging community have created much discussion, and various opinions have been expressed at cataloging conferences and on listservs. ${ }^{3}$ The recommendations of the Library of Congress Working Group

Joan M. Leysen is the Social Sciences Monographs Cataloger at Iowa State University Parks Library; e-mail: jleysen@iastate.edu. Jeanne M.K. Boydston is the Humanities Monographs and Serials Cataloger at Iowa State University Parks Library; e-mail: jboydsto@iastate.edu. 
on the Future of Bibliographic Control will also have implications for those in the cataloging community. ${ }^{4}$ Since it is uncertain how cataloger librarian roles and responsibilities will evolve in the future, it is an opportune time to identify those aspects of a cataloger's work that provide the greatest satisfaction or dissatisfaction. Identifying factors that are favorable in the cataloger's work life can contribute to discussions on redefining the cataloger librarians' role. These data will add to the existing job satisfaction literature by informing library administrators of areas that need attention, such as retention, and can also promote a healthy and positive work environment. In fact, an Association of College \& Research Libraries (ACRL) task force recommends regular quality of work life or job satisfaction surveys as one strategy for assisting with librarian retention. $^{5}$

\section{Literature Review}

There are many definitions of job satisfaction. "Job satisfaction is simply how people feel about their jobs and different aspects of their jobs. It is the extent to which people like (satisfaction) or dislike (dissatisfaction) their jobs." ${ }^{\prime 6}$ Job satisfaction is "... the state of mind that results from an individual's needs or values being met by the job and its environment." ${ }^{\prime 7}$ It is the "... feelings a worker has about his job." $"$

Job satisfaction studies proliferate in the literature and cover a variety of occupational groups. A recent title search of job satisfaction in Sociological Abstracts and PsycINFO retrieved 696 and 4,750 hits respectively. A 2007 Conference Board study reveals a general decline in U.S. job satisfaction from twenty years ago. ${ }^{9}$ Yet, reporting on his and earlier library studies, Van Reenan noted that U.S. workers in general had a 10.6 percent higher job satisfaction rating than library workers. ${ }^{10}$

A number of studies have been published on job satisfaction of library staff. Some of these studies report on overall job satisfaction, and others include satisfaction with specific facets of the job. It is difficult to make comparisons between these studies due to variations in the population studied, type and size of library, facets measured, and methodologies used. Nevertheless, each study adds new interpretations to a growing body of literature in this area. A recent series of articles in Library Journal attests to the continued interest in the study of job satisfaction in libraries. ${ }^{11}$ The first of these articles studied 3,095 library staff, 72 percent of whom indicated they were "satisfied" or "very satisfied" with their jobs. ${ }^{12}$ Job satisfaction is also one of the human resource issues explored in a large study of Canadian libraries. ${ }^{13}$

Several of the library studies include comparisons of demographic variables such as age, gender, and length of service in their analyses of job satisfaction facets. Wahba reported more dissatisfaction among females than males in the fulfillment of esteem and autonomy needs. ${ }^{14}$ However, most studies found no significant relationship between gender and overall job satisfaction. ${ }^{15}$ Mirfakhrai reported a negative correlation with age and job satisfaction. ${ }^{16}$ Chwe found no correlation between age and job satisfaction. ${ }^{17}$ In their 1983 study, Lynch and Verdin noted that library staff with fewer years of experience were less satisfied than the more experienced staff, but this finding was not confirmed in their later study.$^{18}$ Horenstein's findings supported the Lynch and Verdin earlier study, but Mirfakhrai reported a negative correlation between years of service and job satisfaction. ${ }^{19}$

In addition to demographic variables, a number of other aspects have been studied and correlated with job satisfaction. Horenstein reported that librarians with faculty status and rank were more satisfied than other librarians. ${ }^{20}$ Leckie and Brett concurred with Horenstein's findings but added that having administrative responsibilities was more important than academic status in job satisfaction. ${ }^{21}$ Librarians' perceptions that they are in- 
formed and involved in decision making also contribute to higher levels of job satisfaction. ${ }^{22}$ Use of technology, by itself, was not a significant factor in job satisfaction..$^{23}$ Williamson, Pemberton, and Lounsbury's study of job satisfaction and personality traits reported: "Information professionals who were more optimistic, emotionally resilient, team minded, visionary in their work style, and hard working were more likely to report higher levels of job satisfaction..." ${ }^{24}$ Mirfakhrai noted that librarians in smaller libraries were more satisfied than those who worked in larger libraries. ${ }^{25}$ No conclusive studies have been done to link job performance and satisfaction. ${ }^{26}$

Lynch and Verdin examined job satisfaction among specific library units and occupational groups. Job satisfaction was greatest among professional librarians, department heads, first-level supervisors, and reference department staff, as well as jobs with less routine tasks. ${ }^{27}$ In a comparative study of staff at six university libraries, Vaugh and Dunn found no one library had a high satisfaction level with all five dimensions of job satisfaction (pay, work, people, promotion, supervision). ${ }^{28}$ Other studies have examined job satisfaction of paraprofessionals or compared job satisfaction between professionals and paraprofessionals working in libraries. ${ }^{29}$

Investigations of job satisfaction that include catalogers as a specific category of staff are sparse. Although Chwe found catalogers and reference librarians showed no significant differences in overall satisfaction, catalogers were least satisfied with dimensions of creativity, social service, and variety compared to their reference counterparts. ${ }^{30}$ Dissatisfaction with creativity was also reported among Nigerian catalogers. ${ }^{31} \mathrm{D}^{\prime}$ Elia reported no significant differences in job satisfaction between public and technical services beginning academic librarians. ${ }^{32}$ Specialists (catalogers and public services librarians) were found to have the highest satisfaction (69.2\%) compared to supervisors $(46.4 \%)$ and directors $(63.6 \%) .{ }^{33}$ To expand on the findings presented in this literature review, the authors developed a survey to measure job satisfaction of ARL cataloger librarians. The survey instrument is presented in the Appendix found at the end of this article. In this paper, references to specific survey questions are numbered and enclosed in parentheses: for example, (Q17).

\section{Methodology}

One of the crucial steps in conducting a survey is building a viable survey population. The focus of this study was on cataloger librarians who held an MLS or equivalent library degree, had significant hands-on cataloging components in their position responsibilities and were employed at an academic research library. The authors chose to survey the Association of Research Libraries (ARL) member institutions, as they represent a fairly homogenous group. In general, these larger research libraries would employ a number of cataloger librarians from which a sample could be chosen.

Identifying a method for selecting cataloger librarians for this study was difficult. The original plan was to rent American Library Association (ALA) membership lists for the Association for Library Collections \& Technical Services (ALCTS) Cataloging and Classification and Serials Sections. However, the completeness of information contained in the lists was dependent on what the members had provided, making it difficult to select only cataloger librarians. Moreover, the cost to obtain these lists exceeded our set budget. A second approach was to send surveys to library administrators to distribute to cataloger librarians. This method was also rejected because of concern for participant anonymity and confidentiality.

Since our survey population was ARL institutions, the authors located catalogers through member library Web pages. In some cases, the technical services or cataloging departments were very accessible from the library's Web page. In 
other cases it was difficult, and in three instances impossible, to identify a Web presence for the cataloging department or even the technical services division. In contrast, the public services sector of the library was almost always accessible from the homepage.

Once the cataloging homepage was accessed, other problems arose. Ellero points out that most cataloger librarians still have the word "cataloger" somewhere in their position titles. ${ }^{34}$ However, this was not always the case. Identifying the function and responsibilities of some job titles proved to be quite challenging. Also, trying to determine cataloger librarians as opposed to paraprofessionals based solely on the job title was at times close to impossible. In several cases the authors had to identify the titles used for paraprofessional catalogers so those individuals could be eliminated from the names to be selected. Efforts were also made to eliminate catalogers whose job titles indicated major management responsibilities, such as department heads. Once the cataloger librarians were identified, a maximum of three individuals were chosen from each library to be part of the survey population. Both random and nonrandom sampling strategies were used to select the survey population. When possible, an effort was made to include a broad range of cataloger librarians including language and format specialists. It is difficult to judge if the sample population for this survey was representative of cataloger librarians as a whole. Job titles of cataloger librarians may not truly reflect the details of their responsibilities.

The intention of this study was not to follow any one methodology or to replicate a certain study; however, questions were formulated to address issues raised by earlier job satisfaction surveys and the authors' experiences. ${ }^{35}$ The survey instrument consisted of 70 questions in total. Fifty-five questions addressed eight broad dimensions of job satisfaction: roles and responsibilities, workplace culture, administration and supervision, performance evaluation, rewards (salary/benefits), professional development, opportunities, and future concerns. Fifteen questions addressed demographic information. Some questions used multiple choice answers, while others asked respondents to rate their responses on a Likert scale ranging from "strongly disagree" to "strongly agree" (or "not applicable"). One section of the questionnaire asked the respondents to rate certain aspects of the job on a Likert scale in terms of importance and satisfaction. Some questions were vaguely worded in an effort to avoid influencing cataloger responses. However, this also made analysis more difficult. Within the survey, the questions were scrambled (rather than grouped by dimension) to provide variety for the respondents.

The proposed research project including the questionnaire was approved by the Iowa State University Office of Research Assurances Institutional Review Board. The authors also completed the Web-based training on the protection of human subjects in research as is required by Iowa State University. The authors selected the JMP statistical program for analyzing the survey data due to its free access through an Iowa State University subscription and its ease of use. ${ }^{36}$

Many responses to the survey required a rating of 1 to 5 on a Likert scale, reflecting either relative importance, relative satisfaction, or extent of agreement/disagreement. In the interpretation of the findings, ratings of 4 or 5 were considered "high," ratings of 1 or 2 were considered "low," and a 3 rating was considered "neutral." Likewise, "agree" was interpreted as comprising the responses 4 and 5 and "disagree" comprising responses of 1 and 2. "Not applicable" was also an option. In several cases, there were a significant number of neutral responses. It is difficult to know whether these neutral responses were due to indifference or ambivalence. The large number of neutral responses added to the difficulty in drawing conclusions from the data. 


\section{Findings}

This study is designed to complement existing studies of librarians by focusing on a specific group, the cataloger librarian. The study was influenced by personal experiences and evolving issues in the cataloging profession, including:

- The changing roles and responsibilities of professional and paraprofessional catalogers

- The impact of electronic technology on cataloging

- The current place of catalogers and cataloging within the library organization

- The uncertain future of the cataloging profession

- The atmosphere of economic uncertainty in academic libraries

Given these observations, we hypothesized that there would be relatively high levels ( $>50 \%$ ) of dissatisfaction expressed by practicing cataloger librarians, either with regard to specific job related issues, or perhaps even regarding overall job satisfaction.

In May 2007, surveys were mailed to 268 practicing catalogers at $95 \mathrm{ARL}$ academic libraries in the United States. A follow-up e-mail was sent to those who had not responded by the given deadline. A total of 148 surveys were returned; of these, 143 respondents (or $53 \%$ ) met the criteria of being currently employed as a cataloger librarian, holding an MLS or equivalent library degree and agreeing to participate. Every geographic region was represented; however, no responses were received from 14 libraries. This may partially be a reflection of the difficulty in identifying names and functions of catalogers, as mentioned above.

A description of selected elements of the survey population appears in table 1. The population studied included 35 percent males and 65 percent females. Over half of the catalogers were age 50 or older. Eighteen percent were over age 60 , and 5 percent were under age 30 . Twenty-four percent of the catalogers were planning to retire in the next five years. Most cataloger librarians (84\%) in this survey were white Caucasians and work full time (93\%). Excluding the 4 percent who received their degrees in the 1960s, approximately 25 percent of the cataloger librarians surveyed graduated in each of the decades from 1970 to the 2000s. Fifty-five percent of the cataloger librarians had experience of 10 years or less, and 45 percent had more than 10 years of experience. Respondents were divided almost equally between those who had some managerial responsibility and those who did not.

\begin{tabular}{|c|c|}
\hline \multicolumn{2}{|c|}{$\begin{array}{c}\text { TABLE } 1 \\
\text { Demographics of ARL Cataloger } \\
\text { Librarians }\end{array}$} \\
\hline \multicolumn{2}{|l|}{ Age } \\
\hline $25-29$ & $5 \%$ \\
\hline 30-39 & $20 \%$ \\
\hline $40-49$ & $23 \%$ \\
\hline $50-59$ & $35 \%$ \\
\hline $60+$ & $18 \%$ \\
\hline \multicolumn{2}{|l|}{ Ethnicity } \\
\hline Caucasian & $84 \%$ \\
\hline African American & $2 \%$ \\
\hline Asian American & $8 \%$ \\
\hline Native American & $1 \%$ \\
\hline Hispanic/Latino & $3 \%$ \\
\hline Other & $2 \%$ \\
\hline \multicolumn{2}{|l|}{ Year of Degree } \\
\hline $1960 \mathrm{~s}$ & $4 \%$ \\
\hline 1970s & $25 \%$ \\
\hline 1980s & $23 \%$ \\
\hline 1990s & $23 \%$ \\
\hline 2000s & $25 \%$ \\
\hline \multicolumn{2}{|c|}{ Years of Experience as a Cataloger } \\
\hline Fewer than 5 & $31 \%$ \\
\hline $5-10$ & $24 \%$ \\
\hline $11-15$ & $9 \%$ \\
\hline $16-20$ & $15 \%$ \\
\hline More than 20 & $21 \%$ \\
\hline
\end{tabular}




\section{Overall Job Satisfaction}

Eighty-eight percent of the cataloger librarians in this survey were very satisfied $(50 \%)$ or somewhat satisfied $(38 \%)$ with their current job (Q70). According to this study, there was no correlation between overall job satisfaction and demographic factors such as age or gender. Further, 63 percent of the catalogers agreed with the statement "I feel positive about working in the library" (Q13). When asked about professional aspirations for the future (Q6), most cataloger librarians (60\%) did not plan to look for another job; however, 5 percent were seeking a different position in their library.

Twenty-three percent were actively looking for a position in another type of library, but 10 percent wanted a position in another academic library. Only 2 percent were actively looking for a position in another field.

There are many different motivations for seeking employment: salary, various benefits, and professional commitment are but a few. When the respondents in this study were asked, aside from the salary and benefits, how important their current job was in their lives (Q69), the overwhelming majority (94\%) indicated that it was very $(63 \%)$ or somewhat important $(31 \%)$. Only 5 percent felt that their job had little importance in their lives aside from receiving a salary and benefits.

One group of questions (Q35-62) addressed the importance and relative satisfaction respondents felt with certain aspects of their jobs. Using a Likert scale of 1 to 5 plus a "not applicable" option, the respondents were asked to rate, in terms of importance and satisfaction, certain facets of their current positions. The "not applicable" responses were removed, and a median score was calculated for the questions. The median scores for this group of questions are shown on table 2. Eight facets (not in ranked order) emerged with median scores of five (most important):

- Benefits package

- Being consulted about issues directly related to my work
- Being treated fairly, regardless of my gender, race, or ethnicity

- Relationships with coworkers

- Library administration supports catalogers

- My opinions are respected and considered

- Being informed about current activities/issues in my department

- Opportunity to learn new skills

Of these eight facets so highly rated in importance, none received a 5 for satisfaction. All were rated a 4 in satisfaction except for "library administration supports catalogers," which was rated 3.

A second set of questions focused on the degree to which catalogers agreed or disagreed with statements about their jobs. Eliminating the "not applicable" responses, median scores were calculated. A compilation of these median scores appears in table 3. No statement received a 5 for "strongly agree." It is worth noting that a few of these statements are negatively worded (for variety); therefore, by disagreeing with the statement, respondents are actually providing a positive response.

\section{Roles and Responsibilities}

Technological advancements, increased information (especially in electronic form), outsourcing, and budget constraints have resulted in changes to the roles and responsibilities of catalogers. Yet 65 percent of cataloger librarians were comfortable with these changing roles, 10 percent were not, and 24 percent gave a neutral response (Q16). Most cataloger librarians (83\%) reported it was important to have clearly defined duties, although slightly fewer catalogers $(71 \%)$ were satisfied that their duties were clearly defined (Q49).

Some of the work traditionally assigned to the cataloger librarian has been transferred to the paraprofessional, causing a blurring of roles between these two classifications of catalogers. Fortyfour percent of the cataloger librarians indicated it was important to have work 


\begin{tabular}{|c|c|c|c|}
\hline \multicolumn{4}{|c|}{$\begin{array}{c}\text { TABLE } 2 \\
\text { Importance of Job Facets vs. Satisfaction with Job Facets: } \\
\text { Comparison of Median Ratings }\end{array}$} \\
\hline \multicolumn{4}{|c|}{ 5=highest rating; 1=lowest rating (NOTE: Within these three broad categories, job facets are not in ranked order) } \\
\hline & & \begin{tabular}{|c|} 
Importance \\
Rating
\end{tabular} & $\begin{array}{c}\text { Satisfaction } \\
\text { Rating }\end{array}$ \\
\hline \multicolumn{4}{|c|}{ Job facets of highest importance (median rating $=5$ ) } \\
\hline Q36 & Benefits package & 5 & 4 \\
\hline Q37 & Being consulted directly about issues related to my work & 5 & 4 \\
\hline Q39 & $\begin{array}{l}\text { Being treated fairly, regardless of my gender, race, or } \\
\text { ethnicity }\end{array}$ & 5 & 4 \\
\hline Q42 & Relationship with coworkers & 5 & 4 \\
\hline Q44 & Library administration supports catalogers & 5 & 3 \\
\hline Q47 & My opinions are respected and considered & 5 & 4 \\
\hline Q48 & $\begin{array}{l}\text { Being informed about current activities/issues in my } \\
\text { department }\end{array}$ & 5 & 4 \\
\hline Q59 & Opportunity to learn new skills & 5 & 4 \\
\hline \multicolumn{4}{|c|}{ Job facets of high importance (median rating $=4$ ) } \\
\hline Q35 & Salary & 4 & 3 \\
\hline Q38 & My work is valued by individuals outside the department & 4 & 3 \\
\hline Q45 & $\begin{array}{l}\text { Receiving adequate information about changes occurring } \\
\text { librarywide }\end{array}$ & 4 & 3 \\
\hline Q46 & Trust in the library administration & 4 & 4 \\
\hline Q49 & My job duties are clearly defined & 4 & 4 \\
\hline Q50 & My efforts are rewarded appropriately & 4 & 3 \\
\hline Q51 & $\begin{array}{l}\text { Opportunity to participate in library planning and deci- } \\
\text { sion making }\end{array}$ & 4 & 3 \\
\hline Q52 & Opportunity for promotion or advancement within the library & 4 & 3 \\
\hline Q58 & Opportunity to develop leadership skills & 4 & 3 \\
\hline Q60 & Opportunity for variety in responsibilities & 4 & 4 \\
\hline Q62 & Allows research on work time & 4 & 3 \\
\hline \multicolumn{4}{|c|}{ Job facets of medium importance (median rating $=3$ ) } \\
\hline Q40 & Sabbaticals (paid or partly paid leaves) & 3 & 3 \\
\hline Q41 & Research grants & 3 & 3 \\
\hline Q43 & $\begin{array}{l}\text { Work responsibilities clearly differentiated between } \\
\text { paraprofessionals and cataloger librarians }\end{array}$ & 3 & 4 \\
\hline Q53 & Opportunity to supervise others & 3 & 3 \\
\hline Q54 & Opportunity to train others & 3 & 4 \\
\hline Q55 & Opportunity for library committee service & 3 & 4 \\
\hline Q56 & Opportunity for university committee service & 3 & 3 \\
\hline Q57 & Opportunity for leadership & 3 & 3 \\
\hline Q61 & Opportunity for research \& publishing & 3 & 3 \\
\hline
\end{tabular}




\begin{tabular}{|c|c|}
\hline & $\begin{array}{l}\text { TABLE } 3 \\
\begin{array}{l}\text { Agreement/Disagreement with Statements Regarding Job Facets: } \\
\text { Comparison of Median Ratings }\end{array}\end{array}$ \\
\hline \multicolumn{2}{|r|}{$\begin{array}{l}\text { 5=strongly agree; } 4=\text { agree; } 3=\text { neutral; } 2=\text { disagree; } 1=\text { strongly disagree (NOTE: Within these four broad categories, } \\
\text { job facets are not in ranked order) }\end{array}$} \\
\hline \multicolumn{2}{|r|}{ Respondents agree with the following statements (median rating $=4$ ) } \\
\hline Q9 & I am able to balance my work, family, and personal life \\
\hline Q10 & I am comfortable taking leave to care for my family and personal life \\
\hline Q13 & I feel positive about working in this library \\
\hline Q14 & Requirements for tenure and/or advancement are reasonable \\
\hline Q15 & $\begin{array}{l}\text { The emphasis placed on research and publication is appropriately balanced with } \\
\text { daily cataloging responsibilities }\end{array}$ \\
\hline Q16 & I am comfortable with the changing roles/responsibilities of my job \\
\hline Q17 & I feel that I have marketable skills \\
\hline Q20 & The leadership in cataloging is effective \\
\hline Q21 & My supervisor is a competent manager \\
\hline Q22 & I am evaluated annually based on the specific responsibilities of my position \\
\hline Q23 & The time my library devotes to performance evaluations is appropriate \\
\hline Q27 & Catalogers who do a good job are assigned additional work \\
\hline Q29 & I would recommend that recent MLS graduates pursue a career in cataloging \\
\hline Q30 & $\begin{array}{l}\text { If I knew what I know now about the cataloging profession, I would make the same } \\
\text { choice to become a cataloger }\end{array}$ \\
\hline Q32 & Cataloging activities have become deprofessionalized \\
\hline Q33 & My library supports the continuing education/training of its cataloger librarians \\
\hline \multicolumn{2}{|r|}{ Respondents are neutral regarding the following statements (median rating $=3$ ) } \\
\hline Q8 & I have little work-related stress \\
\hline Q11 & There is too much complaining and gossiping in this library \\
\hline Q12 & The physical environment is healthy in this library \\
\hline Q19 & There is too much micromanaging in the library \\
\hline Q28 & $\begin{array}{l}\text { When new technologies or new products are adapted that affect my job, sufficient } \\
\text { training is provided }\end{array}$ \\
\hline Q31 & $\begin{array}{l}\text { Cataloger librarians as we know them today will no longer exist within the next } \\
\text { five years }\end{array}$ \\
\hline Q34 & The raises I receive adequately cover my cost of living \\
\hline \multicolumn{2}{|r|}{ Respondents disagree with the following statements (median rating $=2$ ) } \\
\hline Q18 & There are sufficient numbers of cataloger librarians to perform the work to be done \\
\hline Q25 & I have too much responsibility and authority delegated to me by my supervisor \\
\hline Q26 & I cannot satisfy the conflicting demands of various supervisors \\
\hline \multicolumn{2}{|r|}{ Respondents strongly disagree with the following statement (median rating $=1$ ) } \\
\hline Q24 & My supervisor lacks confidence in my abilities and judgment \\
\hline
\end{tabular}


responsibilities clearly differentiated between cataloger librarians and paraprofessionals (Q43); but 26 percent rated this of low importance, while 30 percent remained neutral. By comparison, over half of the catalogers (54\%) were satisfied with the differentiation of work responsibilities, 14 percent were not satisfied, and 28 percent appeared neutral.

Approximately half of the catalogers agreed $(37 \%)$ or strongly agreed $(17 \%)$ that cataloging activities had become deprofessionalized (Q32). Nineteen percent disagreed, 27 percent replied neutral, and 1 percent indicated not applicable. One cataloger wrote that "cataloging is being downgraded in my institution" and was concerned that paraprofessionals were not receiving support and training for doing original cataloging. Another cataloger commented, "I fear that 'all' cataloging will be outsourced or mechanized." Reflecting on the profession, another cataloger stated, "it's being dumbed down, outsourced \& deprofessionalized."

The declining number of catalogers has continued to be a topic of concern to the cataloging community. This was also a concern of the catalogers in this study. Only 24 percent of the catalogers agreed with the statement "There are sufficient numbers of cataloger librarians to perform the work" (Q18). Fifty-four percent disagreed, 21 percent marked neutral, and 1 percent indicated not applicable. Respondents may have interpreted the question to mean catalogers in general rather than in their specific library. One respondent qualified her or his response, stating that the numbers of catalogers were sufficient in their assigned areas. Several catalogers expressed concerns with vacant positions that might not be filled.

\section{Workplace Culture}

The workplace culture includes many intangible elements, yet it plays a significant role in job satisfaction. A large factor in this culture is the relationships between coworkers.
Eight-eight percent of the respondents in this study indicated that the relations with coworkers were of high importance (Q42). While a majority indicated a high level of satisfaction with their coworkers $(64 \%)$, it is worth noting that a gap does exist between importance and satisfaction in this case. Respondents were specifically asked if excessive complaining and gossiping was a problem in their libraries (Q11). The results were almost evenly divided between those who agreed (34\%) and those who disagreed (36\%). Twentynine percent marked neutral on this issue.

When asked if being treated fairly regardless of gender, race, or ethnicity was important, most respondents $(90 \%)$ agreed or strongly agreed (Q39). However, only 72 percent rated the issue highly in terms of satisfaction.

The ability to balance work and personal commitments was another area covered in the survey. Nine percent of the respondents disagreed with the statement that they were able to balance work, family, and personal life, while 31 percent indicated neutral, 59 percent agreed, and 1 percent marked not applicable (Q9). Additionally, most respondents (66\%) agreed they were comfortable taking leave to care for family or for personal life; only 12 percent disagreed, and 18 percent remained neutral. The "not applicable" category accounted for 3 percent (Q10). Contrary to popular belief, this survey did not find a significant correlation between gender or age and the ability to balance personal and professional responsibilities. However, 40 percent of the respondents disagreed with the statement "I have little work-related stress" (Q8), while slightly less $(37 \%)$ agreed, and 23 percent were neutral.

The physical work environment may also contribute to job satisfaction. Fortyseven percent of the respondents found the physical environment of the library workplace to be healthy; 52 percent, however, indicated either disagreement or selected neutral (Q12). This dissatisfaction may reflect many issues, ranging 
from ergonomics to temperature control in specific libraries, making generalizations regarding these responses impossible.

\section{Administration and Supervision}

The quality of leadership in a library can also contribute to an employee's satisfaction level. A management style that is a good match with employees, and employees who trust the library administration, can contribute to better job satisfaction. Eighty-eight percent of the catalogers felt trust in the library administration was important (39\%) or very important $(49 \%)$, with 9 percent rating this neutral and 2 percent rating it of low importance. However, only 30 percent of catalogers reported satisfaction $(22 \%)$ or high satisfaction $(8 \%)$ with their trust in the library administration (Q46). In fact, 43 percent of the catalogers rated the satisfaction low, 27 percent marked neutral, and 1 percent indicated not applicable. Micromanaging is one criticism often associated with a negative administration or supervision assessment. Approximately one third $(34 \%)$ of the catalogers agreed that there was too much micromanaging in the library, but 43 percent did not agree, 23 percent indicated neutral, and 1 percent marked not applicable (Q19). Some catalogers noted in their written comments that this did occur at times in a particular unit.

Almost all (91\%) catalogers felt that library administration support of catalogers was important. However, catalogers were more divided in their rating of satisfaction of administrative support. Thirty-three percent rated their satisfaction as high, 41 percent rated it low, and 27 percent indicated neutral (Q44). Dissatisfaction with library administration was also reflected in several of the open-ended comments. Administrations were characterized as "weak" or "largely invisible" and "hav(ing) little understanding of the practical concerns of catalogers today." Other catalogers mentioned that too much emphasis was being placed on quantity and that administrators still thought catalogers spent too much time agonizing over records. Another respondent commented that support was provided "only to those involved in digital activities." One cataloger's comments neatly summarized the apparent views of several others: "What we do as catalogers and metadata specialists is not well understood, nor appreciated by the library administration." Another cataloger reflected on library administration resistance to change both nationally and locally.

Most catalogers (83\%) felt it was important to have their work valued outside the department; but only 39 percent were satisfied with the value placed on their work, 24 percent were not satisfied, 36 percent marked neutral, and 1 percent indicated not applicable (Q38). One cataloger noted that since catalogers lack "a visible public presence (and service) we have no opportunity to advertise our skills. We are undervalued and uniformly here feel library administration does not advocate, nor recognize our value." Another cataloger reported that working at the reference desk allowed "non-catalogers to see and appreciate what we do."

Communication is an important factor especially in the continually changing library environment. Not surprisingly, most of the catalogers (85\%) felt it was important to receive adequate information about changes occurring librarywide. Again, catalogers were more divided in their rating of satisfaction, with 38 percent satisfied, 33 percent not satisfied, and 30 percent neutral (Q45). Catalogers also assigned high levels of importance to being informed about activities and issues in their department (89\%) and being consulted about issues directly related to their work (94\%). Yet only 51 percent of the catalogers reported satisfaction on these two questions (Q48, Q37).

Over half $(53 \%)$ of the catalogers in this study agreed that the leadership in cataloging is effective, with 31 percent disagreeing and 16 percent designating 
neutral (Q20). Leadership in cataloging was not defined, and so respondents may have interpreted the question to include leadership at the state or national level as well.

When asked specifically about their supervisors, responses were more favorable. Sixty-three percent of the catalogers agreed that their supervisors were competent managers $(\mathrm{Q} 21)$. Eighty percent of the catalogers felt that their supervisors had confidence in their abilities and judgment (Q24) and approximately the same number $(82 \%)$ did not feel they had too much responsibility and authority delegated to them by their supervisors (Q25). However, supervisors were also faulted for "not representing us catalogers well or strongly to library administration. They also do not follow through on issues that concern catalogers."

In some libraries, catalogers have more than one supervisor. Catalogers were asked to respond to the statement "I cannot satisfy the conflicting demands of various supervisors" (Q26). Eliminating the nonapplicable responses $(17 \%)$, only 15 percent of the catalogers agreed that conflicting demands of multiple supervisors was a problem.

\section{Performance Evaluation}

As mentioned above, research has shown no clear correlation between job satisfaction and job performance. However, aspects of the evaluation process can contribute to overall job satisfaction. The evaluation of staff is a necessary process in any organization, benefiting the employee as well as the employer. Depending on the outcome, evaluations can promote the development of new ideas and initiatives or can result in resentment and continued poor performance. There are numerous methods used in the evaluation process, and no one process fits every organization.

This survey examined the basis of the evaluation, the time devoted to the evaluation process, and the reward for good performance. Seventy-three percent of the catalogers agreed they had an annual evaluation process based on their job position responsibilities (Q22). Written comments indicated that some catalogers had evaluations at different intervals such as every three years. This variation in time could account for the disagree $(9 \%)$, neutral $(11 \%)$, and not applicable $(6 \%)$ responses to this question. Fifty-three percent of the catalogers agreed that the time devoted to their evaluation process was appropriate, 18 percent disagreed, 29 percent marked neutral, and 1 percent indicated not applicable (Q23).

\section{Rewards (Salaries/Benefits)}

In the workplace environment, rewards can take many different forms. Financial rewards, special assignments, recognition by peers, and promotions are only a few of the possibilities. The respondents were asked if their efforts were being rewarded appropriately (Q50). The question was deliberately vague to encompass all types of rewards. Eighty-eight percent of the respondents felt this was of high importance, but only 34 percent-a considerable gap-indicated a high level of satisfaction. No respondents gave a low importance rating to this statement, but 25 percent of the catalogers indicated a low level of satisfaction. Ten percent marked neutral for importance, and 39 percent chose neutral for satisfaction.

Catalogers were also asked whether they agreed or disagreed with the statement "Catalogers who do a good job are assigned additional work" (Q27). This statement was based on an observation of the authors that the reward for good performance is sometimes the assignment of additional work. Awarding additional work can be viewed as positive if it results in a new assignment, position, or challenge. However, if the new assignment is added on top of existing responsibilities and increases the workload, it can have a negative effect. About half (54\%) of the catalogers agreed with this statement, but 15 percent disagreed and 24 percent gave a neutral or not applicable (8\%) response. 
Two of the most important aspects of any position are the salary and the benefits package. Increasingly, however, libraries are facing the double bind of static or decreasing budgets and rising costs of resources. In this environment, significant raises may not always be possible. When comparing the importance of salary with the satisfaction of salary received, 73 percent of the respondents rated salary of high importance, 22 percent marked neutral, and 4 percent rated it low. However, only 39 percent were satisfied with their salaries, 33 percent indicated neutral, and 27 percent were not satisfied (Q35). Only 25 percent of the respondents agreed that their raises adequately covered the cost of living (Q34). Forty-four percent disagreed, 26 percent selected neutral, and 5 percent marked not applicable. This is not surprising: low salaries have always been an issue in the library profession.

Respondents were also queried on the importance versus satisfaction with the benefits package from their libraries (Q36). Ninety-four percent of the respondents rated the benefits package as being of high importance; only 6 percent rated it otherwise. In terms of satisfaction with the benefits package, the neutral category rose sharply, with 20 percent of the respondents indicating that choice. Seventy-four percent of the respondents were satisfied, and 4 percent had lower satisfaction ratings. It is interesting that most respondents rated the benefits package more important than salary. The benefits package may cover a broad range of issues including paid vacation and sick leave, health and life insurance. Considering the high cost of health care, general living expenses, and the uncertain economy, perhaps it's not surprising that 94 percent of the respondents rated this high in importance.

\section{Professional Development}

Professional development is integral to any professional position. It is absolutely essential considering the amount of change witnessed in the library profession in recent years. Professional development may cover a wide spectrum of activities ranging from reading professional journals, attending conferences, mentoring, receiving specialized training or attending continuing education classes. While most respondents $(68 \%)$ agreed that their library supported the continuing education and training of its cataloger librarians (Q33), only 44 percent said that sufficient training was provided for new technologies or new products that affected their specific job (Q28). The response gap between these two seems puzzling. Perhaps the day-to-day training received for new technologies is viewed as different from continuing education. Another possibility is that the library administration supports continuing education in theory, but limited budgets often make its reality difficult. Or perhaps the library administration views some types of continuing education as a personal responsibility rather than a library-sponsored activity.

All the respondents taking part in this survey were cataloger librarians, yet there was a wide range in their current position status (Q5). Almost half of the respondents $(49 \%)$ had a continuing appointment status, while 38 percent were either tenured or tenure track. Thirteen percent indicated "other," and these respondents were omitted from the analysis of questions that addressed tenure, tenure track, or continuing appointment issues. Since the requirements for tenure or continuing appointment vary among institutions, respondents were given the option of indicating "not applicable" as a response to these questions. These "not applicable" responses were not included in the analysis.

Often, scholarly research and publication are required for tenure or continuing appointment. The opportunity to do research and publishing was rated highly (43\%) by the respondents (Q61), and an almost equal percentage indicated a high level of satisfaction with this opportunity 
Job Satisfaction among Academic Cataloger Librarians 285

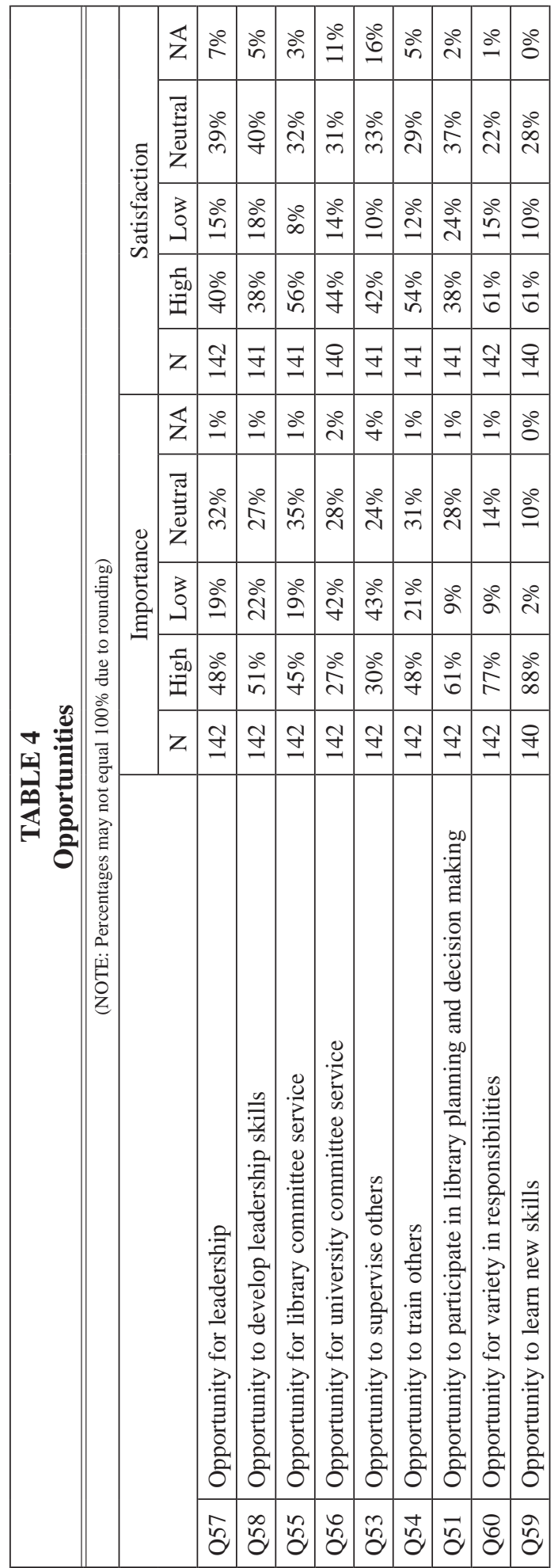

(42\%). However, 30 percent rated it of low importance, and 27 percent were neutral. Forty-four percent were neutral in their degree of satisfaction with this opportunity. The ability to do research on work time (Q62) was important to 61 percent of the respondents, but only 41 percent were satisfied with their ability to do so. Twenty-three percent of the respondents indicated a low importance for this issue, and 25 percent indicated low satisfaction. Sixteen percent of the respondents were neutral on importance, and 34 percent were neutral in terms of satisfaction. The respondents were asked if the emphasis placed on research and publication was appropriately balanced with daily cataloging responsibilities (Q15). Forty-four percent agreed with this statement; however, a sizable group disagreed (34\%), and 21 percent gave a neutral response. Yet, when asked if the requirements for tenure and/ or advancement are reasonable (Q14), 55 percent agreed, while only 21 percent disagreed. The remaining 24 percent felt neutral on the issue.

Sabbaticals (paid or partially paid leaves) and research grants are opportunities provided in academia. The respondents were asked to rate these two facets in terms of importance and satisfaction (Q40, Q41). Most respondents agreed $(40 \%)$ that sabbaticals are important, and 43 percent gave this facet a high level of satisfaction. Research grants were accorded less importance, with only 24 percent of the respondents agreeing to their importance. Forty-seven percent marked neutral on satisfaction with research grants. 


\section{Opportunities}

Catalogers also rated the importance of and satisfaction with opportunities for training and supervising others, committee service, and leadership (Q53-58). Job variety and opportunities to participate in library planning and decision making and to learn new skills were also included (Q51, Q60, Q59). The responses to these opportunities are shown in table 4 . A significant number of neutral responses to some of these questions made the drawing of inferences difficult. Cataloger librarians rated "opportunity to learn new skills" (88\%), "opportunity for variety in job responsibilities" (77\%), and "opportunity to participate in library planning and decision making" $(61 \%)$ highest in importance among the various categories of opportunities. However, only 61 percent were satisfied with the "opportunity for variety in job responsibilities" and "opportunity to learn new skills," and only 38 percent of the catalogers were satisfied with "opportunity to participate in library planning and decision making."

\section{Future Concerns}

Another series of questions focused on what catalogers thought about their future and the future of their positions. Catalogers were asked: if you left your current position, what do you expect would happen to it (Q63)? Almost half $(49 \%)$ of the catalogers felt the position would be filled as a full-time professional position; 31 percent thought it would be reorganized or combined with another position. Only 1 percent thought the position would be filled by a part-time professional, and only 4 percent thought it would be filled by a paraprofessional. Nine percent thought the position would be eliminated. Written comments from the six percent of catalogers who selected "other" indicate they felt the position would be retained but redefined.

The four questions reproduced in table 5 (Q17, Q29-31) were designed to assess catalogers' views on the current status and future of the cataloging profession. At the 2006 Taiga Forum, provocative statements about the future of libraries were presented for discussion. One statement of particular interest was "Within the next five years traditional library organizational structures will no longer

\begin{tabular}{|l|l|c|c|c|c|c|c|}
\hline \multicolumn{7}{|c|}{ TABLE 5 } \\
\hline \multicolumn{7}{|c|}{ Future Concerns of Cataloger Librarians } \\
\hline \hline Qoncentages may not equal 100\% due to rounding) \\
\hline Q17 & $\begin{array}{l}\text { Strongly } \\
\text { agree }\end{array}$ & Agree & Neutral & Disagree & $\begin{array}{c}\text { Strongly } \\
\text { disagree }\end{array}$ & NA \\
\hline $\begin{array}{l}\text { Ifeel that I have market- } \\
\text { able skils }\end{array}$ & $27 \%$ & $46 \%$ & $14 \%$ & $10 \%$ & $3 \%$ & $1 \%$ \\
$\begin{array}{l}\text { Cataloger librarians as } \\
\text { we know them today will } \\
\text { no longer exist within the } \\
\text { next five years }\end{array}$ & $8 \%$ & $20 \%$ & $24 \%$ & $28 \%$ & $20 \%$ & $0 \%$ \\
\hline Q29 & $\begin{array}{l}\text { I would recommend that } \\
\text { recent MLS graduates } \\
\text { pursue a career in cata- } \\
\text { loging }\end{array}$ & $22 \%$ & $32 \%$ & $25 \%$ & $11 \%$ & $10 \%$ & $0 \%$ \\
\hline Q30 & $\begin{array}{l}\text { If I knew what I know } \\
\text { now about the catalog- } \\
\text { ing profession, I would } \\
\text { make the same choice to } \\
\text { become a cataloger }\end{array}$ & $43 \%$ & $24 \%$ & $17 \%$ & $8 \%$ & $7 \%$ & $1 \%$ \\
\hline
\end{tabular}


be functional. Reference and catalog librarians as we know them today will no longer exist..." ${ }^{37}$ Intrigued by this statement, the authors modified it for inclusion in the current survey (Q31). Forty-eight percent of the catalogers disagreed with this statement, including 20 percent who strongly disagreed, indicating that many catalogers feel there is a place for catalogers, at least in the next five years. However, with 28 percent agreeing with the statement and 24 percent marking neutral, there still is concern about the future by about half of the catalogers surveyed. Most catalogers (73\%) agree that they have marketable skills (Q17), and two-thirds (67\%) would make the same choice to become a cataloger knowing what they know now (Q30). There was no correlation between these opinions and the respondents' age or years of service as a cataloger. In addition, over half of the catalogers (54\%) agreed that MLS graduates should pursue a career in cataloging; yet 21 percent disagreed and 25 percent chose neutral (Q29).

\section{Discussion}

Overall, cataloger librarians are satisfied with their jobs, feel their jobs are important, and feel positive about working in the library. This finding mirrors other studies of librarians as a whole. In 1998, Murray found that 81 percent of librarians were either very or moderately satisfied with their jobs. ${ }^{38}$ Hider found the same percentages in 2004..$^{39}$ A Library Journal 2007 study found a slight decline in the satisfaction level of academic librarians, with only 70 percent reporting that they were satisfied or very satisfied. ${ }^{40}$ Low pay and a rapidly changing environment may play into this decline; however, based upon the information garnered in the Library Journal survey, these are only speculations. For the future, most respondents to the present survey planned to remain employed in their current positions. Unlike Berry's results, the present study found no correlation between age and job satisfaction. ${ }^{41}$
Technological advancements, vendorprovided records, budget constraints, and the shift of routine cataloging activities away from cataloger librarians have led some to contemplate whether cataloging activities have become "deprofessionalized." ${ }^{42}$ In a study of professional development activities, catalogers gave "devaluation/deprofessionalization of metadata jobs" as one of the reasons for leaving the metadata field. ${ }^{43}$ Over half of the catalogers in this study agreed that cataloging activities have become deprofessionalized. Yet most catalogers are comfortable with their changing roles and are satisfied that their duties and responsibilities are clearly defined.

Only a small percentage of cataloger librarians are dissatisfied with the distribution of responsibilities between themselves and paraprofessionals. These findings may be an indication that, at least in some libraries, the concern over the blurring of responsibilities is starting to diminish. Some libraries may also have redefined the roles of cataloger librarians. While cataloger librarians may be assuming new roles in management, policy development, digitization, and systems/automation activities in individual libraries, a clear defining role for the cataloger librarian is still being developed in the cataloging community. ${ }^{4}$ Paraprofessional catalogers' responses to these survey questions would provide a more complete picture, since much of the literature indicates that paraprofessional workers in libraries are less satisfied than professionals. ${ }^{45}$

Some of the most important aspects of work life for cataloger librarians revolve around the workplace environment, such as personal respect and relations with coworkers. Other job satisfaction studies have found that relations with coworkers were rated highly by librarians in both the United States and Canada. ${ }^{46}$ A recent Spec Kit on Recruitment and Retention notes that the work environment and relationship with colleagues are also very important in the retention of librarians as a whole. ${ }^{47}$ 
The gap between the high importance and the low satisfaction scores for being treated fairly regardless of gender, race, or ethnicity is reflected in other studies of librarians as a whole. A 1994 study noted that 15 percent of librarians reported discrimination on the bases of sex, ethnic background, or religion. ${ }^{48} \mathrm{~A}$ more recent survey conducted for Library Journal reports that 30 percent of all librarians have experienced discrimination. This discrimination is usually based on gender or age. ${ }^{49}$ However, among librarians under the age of thirty, age bias was the predominant form of discrimination. ${ }^{50}$ Thornton found that 60 percent of ARL librarians of African descent felt that diversity programs were inadequate. ${ }^{51}$

Most cataloger librarians were able to balance professional and personal commitments regardless of age or gender. This was surprising, considering the fact that at least some of the respondents were probably in the "sandwich" generation charged with caring for both dependent children and elderly parents. These findings mirror those of Zemon and Bahr, who studied the effect of motherhood on female academic librarians. They concluded that "...career advancement was possible without the price of motherhood. Although this does not imply that raising children and maintaining a successful full-time career is easy, it does indicate that ... the choice is possible in many academic libraries "52 One possible explanation for the lack of conflict between professional and personal roles may be the increased flexibility of work schedules found in technical services. Another explanation may be the recent "family friendly" policies adopted by many universities. ${ }^{53}$

Support for catalogers and cataloging by the library administration was of high importance to cataloger librarians in this study but something to which they accorded a significantly lower satisfaction rating. Based on survey responses and open-ended comments, many cataloger librarians do not feel their work is under- stood or appreciated. Hider reported that 38 percent of catalogers perceived their expertise was not being recognized by the profession at large, and 25 percent believed it was not being recognized by colleagues in other departments. ${ }^{54}$ In another study of ARL library heads of cataloging departments, 58 percent of these cataloging leaders made no effort to publicize the abilities and skills of catalogers within the library or university. ${ }^{55}$ As catalogers assume new roles and responsibilities in the library organization, more recognition and acknowledgement of their skills and contributions might aid in the job satisfaction of the cataloger librarian and entice new recruits to the field.

A recent library staff job satisfaction study reported much dissatisfaction with managerial competence. ${ }^{56} \mathrm{Administrative}$ management style can also be a predictor of librarian satisfaction in an academic library. ${ }^{57}$ Most catalogers in this study agreed that their supervisors were competent managers and that their supervisors, in turn, have confidence in their abilities and judgment. Slightly over half of the catalogers agreed that the leadership in cataloging was effective. According to an ARL SPEC Kit, the relationship with the supervisor is especially important for job satisfaction and retention of entry-level librarians. ${ }^{58}$

Based on the findings of this study, improving channels of communication can also contribute to increased job satisfaction among cataloger librarians. The catalogers' high ratings of the importance of communication were in sharp contrast to the lower satisfaction scores in this area. Dissatisfaction was over 50 percent when the communication issues related to activities within their department or to their being consulted about issues directly related to their work.

Most catalogers felt their library supports professional development, but not all catalogers agreed that sufficient training was provided for new technologies or products. Keeping up with technological change was listed as the biggest on-the- 
job challenge for academic librarians, according to a recent study. ${ }^{59}$ Another study, however, notes that not a lot of training is offered in management, leadership, and business. ${ }^{60}$ These are exactly the new roles that many cataloger librarians are experiencing. The changing roles of cataloger librarians plus the accelerated rate of technological change make it imperative that cataloger librarians receive adequate training for those changing roles.

Most of the cataloger librarians in this study had either continuing appointments or tenured or tenure-track positions. This study, however, did not mirror Horenstein's findings of a positive correlation between faculty status or rank and job satisfaction. ${ }^{61}$ A slight majority of the respondents rated the opportunity to do research and publishing as high in importance, and most indicated a high level of satisfaction with it. Even more respondents felt the ability to do research on work time was important, but again only a small percentage was satisfied with the ability to do so. Most of the respondents in this survey felt the requirements for tenure or continuing appointment were reasonable. However, sabbaticals and research grants were not seen as important by most respondents.

The future of cataloging and catalogers is at the forefront of professional conversations and in the literature. Wilder has written of the declining numbers of new hires to the cataloging profession and of the projected reduction in numbers of catalogers due to future retirements. ${ }^{62} \mathrm{In}$ light of his findings and similar reports, it is interesting that almost half $(49 \%)$ of the catalogers indicated that, if they left their position, it would be replaced by a full-time professional position and a mere 4 percent reported it would be filled by a paraprofessional. A similar question was asked in a survey of Colorado librarians, where 64 percent of the incumbent librarians thought their successors would meet similar or higher educational requirements and 7 percent thought their positions would be filled by individuals with lower educational requirements. ${ }^{63}$ Some of the respondents in the current study may hold positions that require special language or subject knowledge, qualifications that might be higher priorities for replacement especially in an academic library with specialized collections. However, these positions could be filled by non-MLS subject specialists who hold unique language and subject knowledge if cataloger librarians are not available. ${ }^{64}$ Numbers of cataloger librarians may already be reduced to a minimum in some of these libraries, so replacements might be needed just to maintain the status quo. These findings may also be an indication that many of the cataloger librarians recognize that their duties are transitioning from primarily cataloging activities to including new skills and responsibilities. They anticipate their replacements to have a different set of competencies than those they currently hold. Yet, based on the number of paraprofessionals working in libraries, it seems likely that more of these positions would be replaced by paraprofessionals than what these findings reveal..$^{65}$ It is also likely that the numbers of cataloger librarians will remain small. Much will depend on the future advancements in technology and budgetary issues in individual libraries.

Some cataloger librarians are optimistic about the future of the profession, at least in the short term. Approximately half of the catalogers believe that cataloger librarians as we know them today will continue to exist at least within the next five years. Cataloger librarians believe that catalogers have marketable skills, and they would encourage MLS graduates to pursue a career in cataloging. This response parallels that of librarians in general. Gordon and Nesbeitt reported that 70 percent of the librarians they surveyed would recommend librarianship as a career. However, 25 percent of these librarians noted drawbacks such as low salaries, poor job market, and overemphasis on technology. ${ }^{66}$ Knowing what they know about the cataloging profession, 
two-thirds of the cataloger librarians agreed they would make the same career choice today, and, of these, 43 percent strongly agreed. This also compares favorably with a 2007 study that reported that 86 percent of academic librarians surveyed would choose librarianship as a career if they had to start over. ${ }^{67}$

\section{Limitations}

The limitations of any survey study become all too obvious during the course of the research. Even the most careful examination of the survey questions by both authors and their colleagues failed to remove all ambiguity from the survey. Parts of the importance/satisfaction portion of the survey proved to be very difficult to analyze. For example, a respondent could rate a particular aspect low in importance but high in satisfaction if it was not emphasized in the current position. However, another respondent could rate the same item high in terms of importance and satisfaction because the opportunity was available.

The large number of "neutral" responses to some questions made the analysis difficult. In many cases, the numbers of neutral responses were a significant part of the total. The neutral response was a legitimate option, so it could not be removed from the analysis, but interpreting them was a constant issue. Did the respondents feel ambivalent about the issue? Or were they simply apathetic? Based on the information in the survey, it was impossible to draw conclusions.

The expansion of the sample population of cataloger librarians could potentially validate or disprove the findings of this survey. With a sample population of only 143 respondents, it becomes almost impossible to comment on the validity of the conclusions for the academic cataloger librarian. Asking the same or similar questions of paraprofessional catalogers would also add to a more complete picture of job satisfaction among catalogers.

\section{Conclusion}

The findings of this study failed to support our hypothesis of a relatively high level of dissatisfaction among cataloger librarians. In fact, 88 percent of the cataloger librarians surveyed were very or somewhat satisfied with their current jobs. However, the responses elicited from this survey raised many other questions for future research. Any part of the survey could be used to study special groups of catalogers within the library profession. How do cataloger librarians who are employed in smaller academic, special, or public libraries feel about the issues? Paraprofessional catalogers also need to be surveyed to complete the picture. The survey also raised questions on specific issues. Most of the cataloger librarians in this survey felt that their positions would be filled once they left. However, tight budgets and the increased use of technology are forcing library administrators to make difficult staffing choices. Do the cataloger librarians feel their positions are essential to the library, or are they simply being overly optimistic about the future? If these cataloger librarians are replaced, what will those replacements be doing? Another area for future research revolves around the potential conflict between personal and professional responsibilities. Do paraprofessional catalogers feel comfortable balancing these two aspects of their lives? It is also important to learn more about the changing roles and responsibilities of cataloger librarians in academic librarians. Banush's article describing new roles for cataloger librarians in metadata at Cornell University Library is one example of what is needed. ${ }^{68}$

\section{Notes}

1. In this article, cataloger librarians are defined as those staff who hold an MLS or equivalent library degree and are currently employed in a cataloging position requiring this degree. 


\section{Job Satisfaction among Academic Cataloger Librarians 291}

"Cataloger librarian" and "catalogers" are used interchangeably. The term "paraprofessional" is used to indicate library workers whose positions do not require an MLS or equivalent degree.

2. Jackie Byrd et al., "A White Paper on the Future of Cataloging at Indiana University," Jan. 15, 2006, available online at www.iub.edu/ libtserv/pub/Future_of_Cataloging_White_Paper.pdf [Accessed 19 August 2008]; University of California Libraries, Bibliographic Services Task Force, "Rethinking How We Provide Bibliographic Services for the University of California: Final Report, December 2005," available online at http://libraries.universityofcalifornia.edu/sopag/BSTF/Final. pdf [Accessed 19 August 2008].

3. Some of these papers include: Karen Calhoun, "The Changing Nature of the Catalog and Its Integration with Other Discovery Tools: Final Report March 17, 2006," prepared for the Library of Congress, available online at www.loc.gov/catdir/calhoun-report-final.pdf [Accessed 19 August 2008]; Thomas Mann, "The Changing Nature of the Catalog and Its Integration with Other Discovery Tools: Final Report March 17, 2006, Prepared for the Library of Congress by Karen Calhoun: A Critical Review," Apr. 3, 2006, available online at www.guild2910.org/AFSCMECalhounReviewREV.pdf [Accessed 19 August 2008]; Deanna B. Marcum, "The Future of Cataloging," Library Resources E Technical Services 50, no. 1 (Jan. 2006): 5-9.

4. Library of Congress Working Group on the Future of Bibliographic Control, "On the Record: Report of the Library of Congress Working Group on the Future of Bibliographic Control," Jan. 9, 2008, available online at www.loc.gov/bibliographic-future/news/lcwg-ontherecord-jan08final.pdf [Accessed 19 August 2008]; and the Library of Congress response: Deanna B. Marcum, "Response to On the Record: Report of the Library of Congress Working Group on the Future of Bibliographic Control," June 1, 2008, available online at www.loc.gov/bibliographic-future/news/ LCWGResponse-Marcum-Final-061008.pdf [Accessed 19 August 2008].

5. Association of College \& Research Libraries, Personnel Administrators \& Staff Development Officers Discussion Group, Ad Hoc Task Force on Recruitment \& Retention Issues, "Recruitment, Retention \& Restructuring: Human Resources in Academic Libraries: A White Paper." Final draft May 20, 2002. Available online at

www.ala.org/ala/acrl/acrlpubs/whitepapers/whitepapersreports.htm (ACRL members only). [Accessed 19 August 2008].

6. Paul E. Spector, Job Satisfaction: Application, Assessment, Cause, and Consequences (Thousand Oaks, Calif.: Sage Publications, 1997), 2.

7. Anne H. Hopkins, Work and Job Satisfaction in the Public Sector (Totowa, N.J.: Rowman \& Allanheld, 1983), 32.

8. Patricia Cain Smith, Lorne M. Kendall, and Charles L. Hulin, The Measurement of Satisfaction in Work and Retirement: A Strategy for the Study of Attitudes (Chicago, Ill.: Rand McNally, 1969), 12.

9. Lynn Franco, "U.S. Job Satisfaction Declines: The Conference Board Reports," Feb. 23, 2007. Available online at www.conference-board.org/utilities/pressDetail.cfm?press_ID=3075. [Accessed 19 August 2008].

10. Johann van Reenan, "Librarians at Work; Are We as Satisfied as Other American Workers?" Information Outlook 2, no. 7 (July 1998): 23-28.

11. John N. Berry, "Great Work, Genuine Problems," Library Journal 132, no. 16 (Oct. 1, 2007): 26-29; Andrew Richard Albanese, "Take This Job and Love It," Library Journal 133, no. 2 (Feb. 1, 2008): 36-39; Raya Kuzyk, “I Love Librarianship," Library Journal 133, no. 4 (Mar. 1, 2008): 38-41.

12. Berry, "Great Work, Genuine Problems," 26.

13. 8Rs Research Team, The Future of Human Resources in Canadian Libraries (Edmonton, Alberta: University of Alberta, 2005).

14. Susanne Patterson Wahba, "Job Satisfaction of Librarians: A Comparison between Men and Women," College E Research Libraries 36, no. 1 (Jan. 1975): 49.

15. Mohammad H. Mirfakhrai, "Correlates of Job Satisfaction among Academic Librarians in the United States," Journal of Library Administration 14, no. 1 (1991): 128; George P. D'Elia, "The Determinants of Job Satisfaction among Beginning Librarians," Library Quarterly 49, no. 3 (July 1979): 299; Beverly P. Lynch and Jo Ann Verdin, "Job Satisfaction in Libraries: A Replication," Library Quarterly 57, no. 2 (Apr. 1987): 195; Bonnie Horenstein, “Job Satisfaction of Academic Librarians: An Examination of the Relationships between Satisfaction, Faculty Status, and Participation," College E Research Libraries 54, no. 3 (May 1993): 263; Gloria J. Leckie and Jim Brett, "Job Satisfaction of Canadian University Librarians: A National Survey," College \& Research Libraries 58, no. 1 (Jan. 1997): 43; Steven Seokho Chwe, "A Comparative Study of Job Satisfaction: Catalogers and Reference Librarians in University Libraries," Journal of Academic Librarianship 4, no. 3 (July 1978): 140 .

16. Mirfakhrai, "Correlates of Job Satisfaction," 128.

17. Chwe, "A Comparative Study of Job Satisfaction," 140.

18. Beverly P. Lynch and Jo Ann Verdin, "Job Satisfaction in Libraries: Relationships of the Work Itself, Age, Sex, Occupational Group, Tenure, Supervisory Level, Career Commitment, 
and Library Department," Library Quarterly 53, no. 4 (Oct. 1983): 442; Lynch and Verdin, "Job Satisfaction in Libraries: A Replication," 200.

19. Horenstein, "Job Satisfaction of Academic Librarians," 263; Mirfakhrai, "Correlates of Job Satisfaction," 124.

20. Horenstein, "Job Satisfaction of Academic Librarians," 264.

21. Leckie and Brett, "Job Satisfaction of Canadian University Librarians," 44.

22. Horenstein, "Job Satisfaction of Academic Librarians," 264.

23. Leigh Estabrook, Chloe Bird, and Frederick L. Gilmore, "Job Satisfaction: Does Automation Make a Difference?" Journal of Library Administration 13, no. 1-2 (1990): 182.

24. Jeanine M. Williamson, Anne E. Pemberton, and John W. Lounsbury, "An Investigation of Career and Job Satisfaction in Relation to Personality Traits of Information Professionals," Library Quarterly 75, no. 2 (Apr. 2005): 139.

25. Mirfakhrai, "Correlates of Job Satisfaction," 127.

26. Richard A. Murray, "Job Satisfaction of Professional and Paraprofessional Library Staff at the University of North Carolina at Chapel Hill," master's paper (Chapel Hill: University of North Carolina, 1999), 3; Jack A. Siggins, "Job Satisfaction and Performance in a Changing Environment (Managing Human Resources in Research Libraries)” Library Trends 41, no. 2 (Fall 1992): 303.

27. Lynch and Verdin, "Job Satisfaction in Libraries: A Replication," 197-99.

28. William J. Vaughn and J.D. Dunn, "A Study of Job Satisfaction in Six University Libraries," College E Research Libraries 35, no. 3 (May 1974): 177.

29. Some of these studies include: Murray, "Job Satisfaction of Professional and Paraprofessional Library Staff at the University of North Carolina at Chapel Hill"; Larry R. Oberg et al., "The Role, Status, and Working Conditions of Paraprofessionals: A National Survey of Academic Libraries," College E Research Libraries 53, no. 3 (May 1992): 215-38; Coleen Parmer and Dennis East, "Job Satisfaction among Support Staff in Twelve Ohio Academic Libraries," College E Research Libraries 54, no. 1 (Jan. 1993): 43-57; Donna K. Fitch, "Job Satisfaction among Library Support Staff in Alabama Academic Libraries," College E Research Libraries 51, no. 4 (May 1990): 313-20; Donna K. Fitch, "Update on Job Satisfaction of Library Support Staff," The Alabama Librarian 48, no. 4 (Spring 1998), available online at http://dkfitch.passarola.com/jobsat.html [Accessed 19 August 2008]; Julie Voelck, "Job Satisfaction among Support Staff in Michigan Academic Libraries," College E Research Libraries 56, no. 2 (Mar. 1995): 157-70; Patricia A. Kreitz and Annegret Ogden, "Job Responsibilities and Job Satisfaction at the University of California Libraries," College E Research Libraries 51, no. 4 (July 1990): 297-312.

30. Chwe, "A Comparative Study of Job Satisfaction," 141-42.

31. A.I. Alao, "Job Satisfaction among University Library Cataloguers in Nigeria," World Libraries 7, no. 2 (1997). Available online at www.worlib.org/vol07no2/alao_v07n2.shtml. [Accessed 19 August 2008].

32. D’Elia, "The Determinants of Job Satisfaction among Beginning Librarians," 300.

33. Arvid J. Bloom and Christina W. McCawley, "Job Satisfaction in the Library Profession: Results and Implications from a Pennsylvania Survey," Library Administration \& Management 7, no. 2 (Spring 1993): 93.

34. Nadine P. Ellero, "The Name and Role of the Cataloger in the Twenty-First Century," in Innovative Redesign and Reorganization of Library Technical Services: Paths for the Future and Case Studies, ed. Bradford Lee Eden (Westport, Conn.: Libraries Unlimited, 2004), 127.

35. These surveys include: Spector, Job Satisfaction; 8Rs Research Team, The Future of Human Resources in Canadian Libraries; Nicolle Steffen et al., "Retirement, Retention, and Recruitment: The Future of Librarianship in Colorado," Sept. 2004, available online at www.lrs.org/documents/closer_look/RRR_web.pdf [Accessed 19 August 2008]; Linda Kay Colding, "Predictors of Librarian Turnover Intentions in Public University Librarians," doctoral thesis (University of Alabama, 2004); Richard Bellingham, "Job Satisfaction Survey," available online at www.welcoa. org/freeresources/pdf/job_satisfaction_survey.pdf [Accessed 19 August 2008].

36. JMP Statistical Discovery Software, Version 6.02 (Cary, N.C.: SAS Institute). Available online at www.jmp.com. [Accessed 19 August 2008].

37. Taiga Forum Steering Committee, "Taiga Forum Provocative Statements, March 10, 2006." Available online at www.taigaforum.org/documents/ProvocativeStatements.pdf. [Accessed 19 August 2008].

38. Murray, "Job Satisfaction of Professional and Paraprofessional Library Staff at the University of North Carolina at Chapel Hill," 31-32.

39. Philip Hider, "A Survey of Continuing Professional Development Activities and Attitudes Amongst Catalogers," Cataloging E Classification Quarterly 42, no. 2 (2006): 49.

40. Reed Research Group, "Satisfaction Survey, Library Journal 2007." Available online at www.libraryjournal.com/contents/pdf/satisfaction.pdf. [Accessed 19 August 2008].

41. Berry, "Great Work, Genuine Problems," 27. 


\section{Job Satisfaction among Academic Cataloger Librarians 293}

42. Mary Grenci, "Is Technical Services Being Deprofessionalized? A Report of the ALCTS Role of the Professional in Academic Technical Services Discussion Group Meeting, American Library Association Annual Conference, Washington, D.C., June 1998," Technical Services Quarterly 17, no. 2 (1999): 51-57; Michael Gorman, "The Corruption of Cataloging," Library Journal 120, no. 15 (Sept. 15, 1995): 32-34; Roma Harris, "Information Technology and the De-Skilling of Librarians; or The Erosion of a Woman's Profession," Computers in Libraries 12, no. 1 (Jan. 1992): 8-16; John N. Berry, "The Vanishing Librarians," Library Journal 133, no. 3 (Feb. 15, 2008): 1.

43. Hider, "A Survey of Continuing Professional Development Activities and Attitudes Amongst Catalogers," 50.

44. Lois Buttlar and Rajinder Garcha, "Catalogers in Academic Libraries: Their Evolving and Expanding Roles," College E Research Libraries 59, no. 4 (July 1998): 315; Joan M. Leysen and Jeanne M.K. Boydston, "Supply and Demand for Catalogers: Present and Future," Library Resources $\mathcal{E}$ Technical Services 49, no. 4 (Oct. 2005): 256.

45. Kreitz and Ogden, "Job Responsibilities and Job Satisfaction at the University of California Libraries," 307; Lynch and Verdin, "Job Satisfaction in Libraries: A Replication," 198; Murray, "Job Satisfaction of Professional and Paraprofessional Library Staff at the University of North Carolina at Chapel Hill," 31-32.

46. Horenstein, "Job Satisfaction of Academic Librarians," 258; Leckie and Brett, "Job Satisfaction of Canadian University Librarians," 36-37.

47. Jen Stevens and Rosemary Streatfeild, Recruitment and Retention, SPEC KIT 276 (Chicago, Ill.: Association of Research Libraries, Office of Leadership and Management Services, Sept. 2003), 12.

48. Evan St. Lifer, "Are You Happy in Your Job? LJ's Exclusive Report," Library Journal 119, no. 18 (Nov. 1, 1994): 46.

49. Reed Research Group, "Satisfaction Survey, Library Journal 2007."

50. Berry, "Great Work, Genuine Problems," 29.

51. Joyce K. Thornton, "Job Satisfaction of Librarians of African Descent Employed in ARL Academic Libraries," College E Research Libraries 61, no. 3 (May 2000): 224.

52. Mickey Zemon and Alice Harrison Bahr, "Career and/or Children: Do Female Academic Librarians Pay a Price for Motherhood?" College E Research Libraries 66, no. 5 (Sept. 2005): 402.

53. U.S. Equal Employment Opportunity Commission, "EEOC Issues New Guidance on Work/ Family Balance and Promotes Employer Best Practices," May 23, 2007. Available online at www. eeoc.gov/press/5-23-07.html. [Accessed 19 August 2008].

54. Hider, "A Survey of Continuing Professional Development Activities and Attitudes Amongst Catalogers," 48-49.

55. Leysen and Boydston, "Supply and Demand for Catalogers," 256.

56. Berry, "Great Work, Genuine Problems," 26.

57. Dale Susan Bengston and Dorothy Shields, "A Test of Marchant's Predictive Formulas Involving Job Satisfaction," Journal of Academic Librarianship 11, no. 2 (May 1985): 91.

58. Stevens and Streatfeild, Recruitment and Retention, 25.

59. Reed Research Group, "Satisfaction Survey, Library Journal 2007."

60. 8Rs Research Team, The Future of Human Resources in Canadian Libraries, 6.

61. Horenstein, “Job Satisfaction of Academic Librarians," 260.

62. Stanley J. Wilder, "Demographic Trends Affecting Professional Technical Services Staffing

in ARL Libraries," Cataloging \& Classification Quarterly 34, no. 1-2 (2002): 52.

63. Steffen et al., "Retirement, Retention, and Recruitment," 76.

64. Bill Crowley, “Just Another Field?" Library Journal 129, no. 18 (Nov. 1, 2004): 44-46.

65. JoAnne Deeken and Deborah Thomas, "Technical Services Job Ads: Changes Since 1995,"

College E Research Libraries 67, no. 2 (Mar. 2006): 141; Oberg et al., "The Role, Status, and Working

Conditions of Paraprofessionals," 221.

66. Rachel Singer Gordon and Sarah Nesbeitt, "Who We Are, Where We're Going: A Report from the Front," Library Journal 124, no. 9 (May 15, 1999): 39.

67. Reed Research Group, "Satisfaction Survey, Library Journal 2007."

68. David Banush, "Stepping Out: The Expanding Role of Catalogers in Academic Libraries and Academic Institutions," Cataloging E Classification Quarterly 45, no. 3 (2008): 81-90. 


\section{Appendix}

A Survey of Cataloger Librarians

Please complete the following information about your background and current employment as a cataloger.

For this study, a Cataloger librarian is defined as a person who:

has an MLS or equivalent library degree

AND

is currently employed in a cataloging position requiring this degree

1. Based on the definition above, are you currently employed as a cataloger?

$1=$ yes

$2=$ no $\rightarrow$ Please return the survey

2. When did you receive your library degree?

$1=1960$ s

$2=1970$ s

$3=1980 \mathrm{~s}$

$4=1990 \mathrm{~s}$

$5=2000 \mathrm{~s}$

3. How many years have you worked as a cataloger in your current position?

$1=$ Less than 5 years

$2=5-10$ years

$3=11-15$ years

$4=16-20$ years

$5=$ More than 20 years in current position

4a. Do you work part time or full time?

$1=$ Part time

$2=$ Full time $\rightarrow \quad 4 \mathrm{~b}$. Is your time split between cataloging and another area/department of the library? $1=$ Yes $2=\mathrm{No}$

5. What is your current status?

$1=$ Tenured

$2=$ Tenure Track

$3=$ Continuing Appointment

$4=$ Other (Please specify)

6. Which of the following statements best describes your aspirations for the future?

$1=I$ do not plan to look for another job

$2=$ I would like to work in a different position in my current academic library

$3=\mathrm{I}$ am actively looking for a position in another academic library

4=I am actively looking for a position in another field altogether

$5=\mathrm{I}$ am actively looking for a position in another type of library

$6=$ Other

7. Do you plan to retire in the next 5 years?

$1=$ yes

$2=$ no 
Job Satisfaction among Academic Cataloger Librarians 295

\begin{tabular}{|c|c|c|c|c|c|c|}
\hline $\begin{array}{l}\text { Please indicate to what extent you disagree or agree with each } \\
\text { of the following statements. Circle number: } 1=\text { strongly disagree; } \\
5=\text { strongly agree; or Not Applicable (NA). }\end{array}$ & \multicolumn{2}{|c|}{$\begin{array}{l}\text { Strongly } \\
\text { Disagree }\end{array}$} & \multicolumn{2}{|c|}{$\begin{array}{l}\text { Strongly } \\
\text { Agree }\end{array}$} & \multicolumn{2}{|c|}{$\begin{array}{c}\text { Not } \\
\text { Applicable }\end{array}$} \\
\hline 8. I have little work-related stress & 1 & & 3 & 4 & 5 & NA \\
\hline 9. I am able to balance my work, family and personal life & 1 & 2 & 3 & 4 & 5 & NA \\
\hline $\begin{array}{l}\text { 10. I am comfortable taking leave to care for my family and } \\
\text { personal life }\end{array}$ & 1 & 2 & 3 & 4 & 5 & NA \\
\hline 11. There is too much complaining and gossiping in this & 1 & 2 & 3 & 4 & 5 & NA \\
\hline 12. The physical environment is healthy & 1 & 2 & 3 & 4 & 5 & NA \\
\hline 13. I feel positive about working in this library & 1 & 2 & 3 & 4 & 5 & NA \\
\hline 14. Requirements for tenure and/or advancement are re & 1 & 2 & 3 & 4 & 5 & NA \\
\hline $\begin{array}{l}\text { 15. The emphasis placed on research and publication is appropri- } \\
\text { ately balanced with daily cataloging responsibilities }\end{array}$ & 1 & 2 & 3 & 4 & 5 & NA \\
\hline $\begin{array}{l}\text { 16. I am comfortable with the changing roles/responsibilities } \\
\text { of my job }\end{array}$ & 1 & 2 & 3 & 4 & 5 & NA \\
\hline 17. I feel that I have marketable skills & 1 & 2 & 3 & 4 & 5 & NA \\
\hline $\begin{array}{l}\text { 18. There are sufficient numbers of catalogers to perform the } \\
\text { work to be done }\end{array}$ & 1 & 2 & 3 & 4 & 5 & NA \\
\hline 19. There is too much micro-managing in th & 1 & 2 & 3 & 4 & 5 & NA \\
\hline 20. The leadership in cataloging is effective & 1 & 2 & 3 & 4 & 5 & NA \\
\hline 21. My supervisor is a competent manager & 1 & 2 & 3 & 4 & 5 & NA \\
\hline $\begin{array}{l}\text { 22. I am evaluated annually based on the specific responsibilities } \\
\text { of my position }\end{array}$ & 1 & 2 & 3 & 4 & 5 & NA \\
\hline $\begin{array}{l}\text { 23. The time my library devotes to performance evaluations is } \\
\text { appropriate }\end{array}$ & 1 & 2 & 3 & 4 & 5 & NA \\
\hline 24. My supervisor lacks confidence in my abilities and judgment & 1 & 2 & 3 & 4 & 5 & NA \\
\hline $\begin{array}{l}25 . \text { I have too much responsibility and authority delegated to } \\
\text { me by my supervisor }\end{array}$ & 1 & 2 & 3 & 4 & 5 & NA \\
\hline 26. I cannot satisfy the conflicting demands of various supervisors & 1 & 2 & 3 & 4 & 5 & NA \\
\hline 27. Catalogers who do a good job are assigned additional work & 1 & 2 & 3 & 4 & 5 & NA \\
\hline $\begin{array}{l}\text { 28. When new technologies or new products are adapted that } \\
\text { affect my job, sufficient training is provided }\end{array}$ & 1 & 2 & 3 & 4 & 5 & NA \\
\hline $\begin{array}{l}29 . \text { I would recommend that recent MLS graduates pursue a } \\
\text { career in cataloging }\end{array}$ & 1 & 2 & 3 & 4 & 5 & NA \\
\hline $\begin{array}{l}\text { 30. If I knew what I know now about the cataloging profession, } \\
\text { I would make the same choice to become a cataloger }\end{array}$ & 1 & 2 & 3 & 4 & 5 & NA \\
\hline $\begin{array}{l}\text { 31. Catalog librarians as we know them today will no longer exist } \\
\text { within the next five years }\end{array}$ & 1 & 2 & 3 & 4 & 5 & NA \\
\hline 32. Cataloging activities have become deprofessionalized & 1 & 2 & 3 & 4 & 5 & NA \\
\hline $\begin{array}{l}\text { 33. My library supports the continuing education/training of its } \\
\text { cataloger librarians }\end{array}$ & 1 & 2 & 3 & 4 & 5 & NA \\
\hline 34. The raises I receive adequately cover my cost of living & 1 & 2 & 3 & 4 & 5 & NA \\
\hline
\end{tabular}




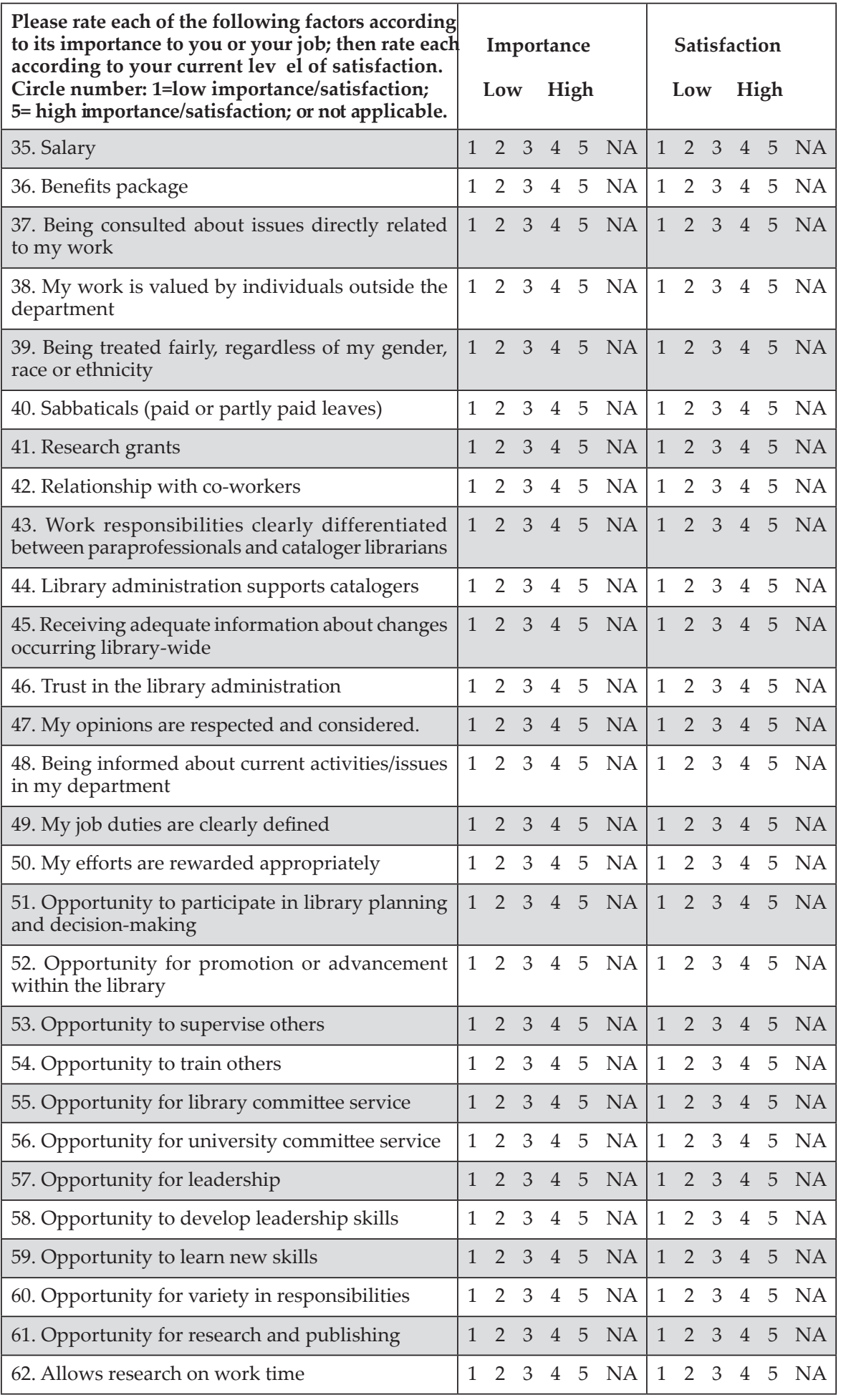


63. If you left your current position, what do you expect would happen to it. Select only one response.

$1=$ Reorganize or combine this position with another position

$2=$ Would be filled as a full time professional position

$3=$ Would be filled as a part-time professional position

$4=$ Would be filled as a paraprofessional position

$5=$ Would be eliminated

$6=$ Other (Please specify)

64. Does your current position include managerial responsibilities?

(Managerial responsibilities include budget and hiring responsibilities, conducting performance appraisals, supervising and training, etc.)

$1=$ yes

$2=$ no

65. What is your gender?

$1=$ Male

2=Female

66. What is your race or ethnicity?

$1=$ Caucasian

$2=$ African American

3=Asian American

4=Native American

$5=$ Hispanic/Latino

$5=$ Other

67. What is your age?

$1=$ under 25

$2=25-29$

$3=30-39$

$4=40-49$

$5=50-59$

$6=60$ and over

68. Is your salary?

$1=\$ 30,000$ and under

$2=\$ 31,000-40,000$

$3=\$ 41,000-50,000$

$4=\$ 51,000$ and higher

69. Aside from the salary and benefits, how important is your job in your life?

$1=$ very

$2=$ somewhat

$3=$ little

70. Overall, how satisfied are you with your current job?

$1=$ very

$2=$ somewhat

$3=$ little

Comments: 